\title{
A Revision of "the Irish Exception": Seán Murphy, Irish Recognition Policy and the Republic of France, 1944
}

Mervyn O'Driscoll

\section{(2) OpenEdition}

Journals

Electronic version

URL: http://journals.openedition.org/etudesirlandaises/4816

DOI: $10.4000 /$ etudesirlandaises.4816

ISSN: 2259-8863

Publisher

Presses universitaires de Rennes

Printed version

Date of publication: 15 June 2016

Number of pages: $73-94$

ISBN: 978-2-7535-5091-9

ISSN: 0183-973X

Electronic reference

Mervyn O'Driscoll, «A Revision of "the Irish Exception": Seán Murphy, Irish Recognition Policy and the Republic of France, 1944 », Études irlandaises [Online], 41-1 | 2016, Online since 15 June 2018, connection on 19 April 2019. URL : http://journals.openedition.org/etudesirlandaises/4816 ; DOI : 10.4000/etudesirlandaises.4816 


\title{
A Revision of "the Irish Exception": Seán Murphy, Irish Recognition Policy and the Republic of France, 1944
}

\author{
Mervyn O’Driscoll \\ University College Cork
}

\begin{abstract}
The article reframes Irish wartime neutrality. It posits that Ireland's policy towards Vichy France conformed to the prevailing legal interpretations in the field of diplomatic recognition. This was consistent with the practice of Ireland's longstanding recognition policy from the 1930s until the 1960s. An enigma, however, envelops Ireland's retention of the Irish Minister to the Republic of France, Seán Murphy, after the fall of Marshall Philippe Pétain in August 1944. Charles de Gaulle's Provisional Government demanded the replacement of all heads of missions who had served in France during the Vichy interlude. This violated the traditional practice of recognition law as understood by Ireland and other neutrals. But the neutrals, with the exception of Ireland, reluctantly complied with the demand. How did the Irish Department of External Affairs succeed in circumventing this? No evidence of an illusive "back channel", that some authors speculate ended the accreditation crisis, has been found. There is limited evidence that secondary factors, such as the proposed establishment of an Irish Red Cross Hospital in Normandy, played a direct or significant role in senior French decision makers' calculations to reverse their policy in the case of Murphy. This article offers a fresh explanation for France's extension of a dispensation to Ireland: on petition from the Irish government, René Massigli, the new French Ambassador in London, made two decisive interventions which altered the climate of opinion in Paris and enabled Seán Murphy to remain. "We had no quarrel with any group of Frenchmen and our one desire with regard to France was to see her whole people united under one Government... We did not want quarrels between Frenchmen in Ireland ${ }^{1}$."
\end{abstract}

Keywords: Word War II, Irish neutrality, Vichy, recognition policy, international relations

\section{Résumé}

L'article apporte une nouvelle perspective sur la neutralité irlandaise en temps de guerre. Le postulat de départ est que la stratégie irlandaise envers le gouvernement français de Vichy était conforme aux interprétations légales de l'époque dans le domaine des relations diplomatiques. Ceci correspondait avec la politique de relations internationales irlandaise depuis les années 1930 et jusque dans les années 1960. Le fait que l'ambassadeur irlandais de la République française, Seán Murphy, soit resté en poste après la chute du maréchal Pétain en août 1944 reste cependant une énigme. Le gouvernement provisoire de Charles de Gaulle a en effet exigé le replacement de tous les chargés de missions ayant officié en France durant l'interlude de Vichy, ce qui allait à l'encontre des habi-

1. Minute by J. P. Walshe, 22 June 1944 (National Archives of Ireland, Dublin [hereafter NAI], Department of Foreign Affairs [hereafter DFA], Secretary's Office Files [hereafter SOF], A. 2). 
tudes de l'Irlande et des autres pays neutres en matière de relations diplomatiques. Les pays neutres, à l'exception de l'Irlande, furent quand même forcés de se soumettre à cette volonté. Comment le ministère des Affaires Extérieures irlandais a-t-il réussi à contourner cet écueil? Aucune preuve de l'existence d'un illusoire "canal alternatif", auquel certains auteurs attribuent la fin de la crise des habilitations, n'a jamais été révélée. Il n'existe que peu d'éléments confirmant l'influence directe ou significative de facteurs secondaires, comme la proposition de construction d'un hôpital de la Croix Rouge irlandaise en Normandie, sur le changement de politique des décisionnaires français en ce qui concerne Murphy. Cet article offre une nouvelle explication à la dispense accordée à l'Irlande par la France : René Massigli, le nouvel ambassadeur français à Londres, est intervenu deux fois de façon décisive, grâce à une pétition du gouvernement irlandais, et a influencé les courants d'opinion à Paris, permettant à Sean Murphy de rester à son poste. "Nous n'avions pas de différends avec aucune faction française, et notre plus cher désir concernant la France était de voir son peuple uni sous un seul et même gouvernement... Nous ne voulions pas créer de tensions à l'intérieur de la communauté française en Irlande."

Mots clés : Seconde Guerre mondiale, neutralité irlandaise, Vichy, politique de reconnaissance, relations internationales

\section{圈 Introduction}

Ireland holds an intriguing but ambiguous privilege: it was the only neutral state permitted to retain its diplomatic representative to France into the postliberation period by Charles de Gaulle's Provisional Government (Gouvernement provisoire de la République française or GPRF). His Irish counterpart was Eamon de Valera and parallels are sometimes drawn between the two, not least in their self-ascribed roles as national conservatives, statebuilders and as interpreters of the national will ${ }^{2}$. Eamon de Valera held the portfolio of Taoiseach, in addition to that of Minister for External Affairs, which granted authority to the Department of External Affairs domestically and internationally. The department was based in Iveagh House, Dublin, and during the period of August, September and October 1944 it struggled for the recognition of Seán Murphy as the Irish Minister to the Republic of France by the new French government. Murphy had served as the Irish Minister Plenipotentiary and Envoy Extraordinary to the Republic of France since 1938. Dublin viewed the GPRF's acquiescence to Murphy's continuation in post as an incontestable right and a validation of Ireland's entitlement to pursue neutrality.

Previous Irish diplomacy vis-à-vis Vichy was indistinguishable from that of the other European neutrals, in particular that of the traditional neutrals Switzerland

2. Diarmaid Ferriter, Judging Dev, Dublin, Royal Irish Academy, 2007, p. 4, 5. Cf. J.J. Lee, Ireland 1912-1985: Politics and Society, Cambridge, Cambridge University Press, 1989, p. 342. 
and Sweden which were viewed in Irish diplomatic circles as setting the benchmark for neutrality. The "Irish exception" has fascinated authors such as Dermot Keogh, Robert Patterson, Phyllis Gaffney, Christophe Gillissen and Joe Carroll, who have endeavoured to account for the consideration shown to Ireland ${ }^{3}$. The challenge is that the documentary record is fragmentary and confused. This reflects the chaotic conditions in France in late 1944 during and immediately after liberation leading to delays in the Provisional Government's installation and the Quai d'Orsay's re-establishment in Paris. Communications were disrupted as the Allies prioritised the prosecution of the war against Nazi Germany.

This article contends it was not the tentative "Irish back channel", suggested by Dermot Keogh and Robert Patterson ${ }^{4}$, which ensured de Gaulle's dramatic intercession to retain Seán Murphy. Keogh calculated that the close relationship between Frederick Boland and Hervé Alphand contributed to the accomplishment of the Irish opt-out ${ }^{5}$. Hervé was the son of Charles Alphand, the first French Minister to Ireland (appointed 1930). He adhered to the CFLN and advised de Gaulle on economic affairs, becoming Director General of Economic Affairs in the Quai d'Orsay in September 1944․ By 1944 Boland was the Assistant Secretary of the Department of External Affairs and he knew Hervé Alphand well from the early 1930s. A sister of Hervé Alphand was married to an Irishman, Michael FitzGerald. Keogh and Patterson speculated that the BolandAlphand personal associations secured the Irish a hearing with de Gaulle for their right to retain Murphy. They pointed out that in early October 1944 de Gaulle requested that the Quai d'Orsay explain why Murphy had been "badly received" and demanded an explanation from the French foreign minister, Georges Bidault,

3. Dermot Keogh, Ireland and Europe 1919-1989: A Diplomatic and Political History, Cork and Dublin, Hibernian, 1989, p. 138-41, 156-60, 182-9; Joe Carroll, "A French View of Irish Neutrality”, Études Irlandaises, xIv: 2 (Dec. 1991), p. 159-164; Dermot Keogh, "Ireland, de Gaulle and World War II", in Pierre Joannon, De Gaulle and Ireland, Dublin, Institute of Public Administration, 1991, p. 23-52; Phyllis Gaffney, "Why was Ireland given Special Treatment? The Awkward State of Franco-Irish Diplomatic Relations, August 1944-March 1945", Études Irlandaises, xxIv, $\mathrm{n}^{\circ} 1$ (Spring 1999), p. 151-62; Robert Patterson, "Ireland, Vichy and Post-Liberation France, 1938-50", in Michael Kennedy and J. M. Skelly (eds), Irish Foreign Policy 1919-1966: From Independence to Internationalism (Dublin, 2000), p. 96-115; Christophe Gillissen, "France”, in Mervyn O’Driscoll, Dermot Keogh and Jérôme aan de Wiel (eds.), Ireland through European Eyes: Western Europe, the EEC and Ireland, 1945-1973, Cork, Cork University Press, 2013, p. 78-80. These empirical studies were invaluable, and Keogh's work was pioneering.

4. Dermot Keogh, "Ireland, de Gaulle and World War II", art. cit., p. 23-52; Robert Patterson, "Ireland, Vichy and Post-Liberation France, 1938-50”, art. cit., p. 96-115.

5. Dermot Keogh, Ireland and Europe, op. cit., p. 187; Dermot Keogh, "Ireland, de Gaulle and World War II", art. cit., p. 24; Robert Patterson, "Ireland, Vichy and Post-liberation France”, art. cit., p. 111.

6. "Ex-French Ambassador Hervé Alphand Dies", Washington Post, 19 January 1994, [https://www.washingtonpost.com/archive/local/1994/01/19/ex-french-ambassador-herve-alphand-dies/6652ccde-eab6-4b128918-bd38bd0f4d57/ (accessed 14 February 2016); "Deaths Elsewhere: Hervé Alphand, 86 an aide to Charles de Gaulle during...", Baltimore Sun, 19 January 1994. [http://articles.baltimoresun.com/1994-01-19/ news/1994019076_1_gaulle-ambassador-prime-minister] (accessed 14 February 2016). 
accounting for the state of the bilateral relationship. He argued that France "should attach care and importance" to the relationship ${ }^{7}$. But Keogh supplied no documentary or oral evidence for the Alphand "back channel" that he claimed was responsible for de Gaulle's dramatic intervention. This suggestion of an Alphand "back channel" has influenced subsequent authors' interpretations.

Phyllis Gaffney has presented "a slightly different - though perhaps complementary - perspective on the affair ${ }^{8 "}$. Her findings emerged from her research on the establishment of an Irish Red Cross hospital in Normandy. This initiative, heavily supported by the Irish government, was designed to alleviate the suffering of the inhabitants of Saint-Lô in late 1944 and 1945 . Saint-Lô was one of the settlements ravaged by vicious town-to-town fighting between Allied and German forces in Normandy after D-Day. Gaffney reasoned France's desperate need for medical philanthropy was one component of a multifactorial calculation at the heart of de Gaulle's exceptional treatment of Murphy. She contends that le médecin-général, Adolphe Sicé, a follower of de Gaulle since 1940 , was a strong supporter of the Irish humanitarian initiative. He had responsibility for the medical relief of Normandy following D-Day. Through his strong links with the French Red Cross, Gaffney contends, he encouraged the Irish Red Cross to implement its offer of relief. Medical supplies and trained medical personnel were scarce in France in late $1944^{10}$. But Gaffney adduced no evidence that Sicé petitioned de Gaulle to seek a dispensation for Murphy in order to smooth the Irish decision to proceed with setting up of the SaintLô Hospital. Sicé does not appear in the Quai d'Orsay or Charles de Gaulle papers associated with the Murphy accreditation crisis. Gaffney's thinking is certainly appealing, but if Saint-Lô was a factor motivating the French reversal on Murphy's status, it was a marginal or intangible consideration. It was not the primary cause.

Gaffney has also reasoned that either the Quai or de Gaulle, or both, calculated that Éire's distant and anomalous membership of the British Commonwealth could be exploited to expand French influence. She highlighted the prospect of improved air and sea links between France and Ireland, and the opportunity of introducing the French language as a subject in secondary schools. This would flatter French national pride at a psychic level following the humiliations of World War Two ${ }^{11}$. However, French ambitions to expand its influence were less than acute in early October 1944, especially in such a marginal region as Ireland; the

7. Charles de Gaulle, Lettres, Notes et Carnets, Juin 1943-Mai 1945 (Paris, 1983), p. 327-328.

8. Phyllis Gaffney, "Why was Ireland given Special Treatment?", art. cit., p. 153.

9. Phyllis Gaffney, Healing Amid the Ruins: The Irish Hospital at Saint-Lô (1945-46), Dublin, A \& A Farmar, 1999.

10. Phyllis Gaffney, “Why Was Ireland given Special Treatment?", art. cit., p. 158.

11. Ibid., passim. 
GPRF struggled with the more immediate concern of instituting effective control over the French ship of state.

One argument proposed by Gaffney, however, has a more direct bearing on French calculations. The Quai d'Orsay appreciated Iveagh House's arguments that a French request for new letters of credence for either Murphy or for a replacement for Murphy would open "a can of worms": King George VI, as head of the British Commonwealth, had to confirm all new letters of credence including Éire's ${ }^{12}$. Gaffney was correct in observing that Anglo-Irish relations were strained - the British Prime Minister Winston Churchill was a harsh and unrelenting critic of both Irish neutrality and independence. Neutrality was anomalous in the British Commonwealth: all the other white Dominions supported the British war effort. Iveagh House avoided requesting that King George VI sign new letters of credence after neutrality was declared. Gaffney suggested that GPRF preferred to avoid entanglement in this delicate matter ${ }^{13}$. There is value in this line and the article supports the contention that such calculations contributed to France's flexibility towards Seán Murphy. However, they were secondary rather than primary considerations.

This article argues for a revision of existing views. It explores Christophe Gillissen's recent argument that the Quai d'Orsay forwarded the recommendation of the French Ambassador in London, René Massigli, to de Gaulle, and that this was what initiated the reversal of French policy. Gillissen does not explain who in the Quai took the unusual step of forwarding Massigli's advice to the President ${ }^{14}$. Gillissen's proposal deserves deeper investigation. This article supports the contention: it was René Massigli who secured the Quai's turnaround in Ireland's favour. He interceded with the Quai not once, but twice, and both times he secured a sympathetic hearing for Ireland's case defusing the diplomatic crisis. He was the catalyst who ensured Iveagh House's case in favour of Seán Murphy was heeded in Paris. It was not just Charles de Gaulle who transformed the intransigence of the officers of the Quai; Georges Bidault, the Foreign Minister, also played a noteworthy role in adopting an accommodating approach to Seán Murphy and Charles de Gaulle's intervention simply reinforced the Bidault revision. Bidault's role has been completely ignored by all previous authors. This article finds, however, Keogh's explanation for the resolution of the crisis is not invalid - an older Irish-French diplomatic link assisted in the resolution of the crisis, though it was by accident not design and Hervé Alphand was not involved.

12. Phyllis Gaffney, "Why was Ireland given Special Treatment?”, art. cit., p. 155; Laforcade to Affaires Étrangères, Télégramme, 19 September 1944 (Affaires étrangères - Archives Diplomatiques [hereafter AEAD], série Europe 1944-1970, sous-série Irlande, vol. 219, n³)

13. Phyllis Gaffney, "Why was Ireland given Special Treatment?", art. cit., p. 154.

14. Christophe Gillissen, "France”, art. cit., p. 78-80. 
One might be forgiven for claiming all of this scholarly argument surrounding Murphy's retention as the Irish Minister is arcane, but it is not. From de Valera and Joe Walshe's perspectives, neutrality depended on external perception and adherence to diplomatic protocol. When Murphy gained permission to remain as Irish Minister, it was an "implicit concession ${ }^{15}$ " signifying French respect for neutrality and the probity of Irish arguments. Dermot Keogh was correct: French acquiescence on the matter was a significant "diplomatic achievement" from the de Valera's and Walshe's perspectives ${ }^{16}$; it was perceived as an endorsement of the integrity of Irish neutrality.

This article has two parts. First, the article frames Irish recognition policy within the setting of Irish neutral diplomacy toward the French republic after the Fall of France in May 1940. It illustrates how Irish policymakers, in particular Joseph Walshe, mediated between the competing claims of French factions for recognition. De Gaulle and his Free French movement became the focal point for resistance against Vichy. De Gaulle represented the Comité française de la Libération nationale (CFLN) as the "alternative France ${ }^{17}$ ", deserving de jure recognition as the legitimate government of the Republic of France. Following the liberation of France in late summer 1944, he declared the CFLN was the Provisional Government of France (GPRF). This article does not follow the intricate twists and turns of the Vichy and anti-Vichy forces, or the Irish interpretation thereof, for reasons of complexity and space; these are adequately outlined elsewhere ${ }^{18}$. Instead, it evaluates Irish diplomacy towards France in a comparative and legal light. Unlike previous work, it contextualises Irish diplomacy towards the French state after May 1940 within the milieu of the recognition policy practiced by other states at the time, particularly the neutrals and Allies. The initial sections of this article propose that Ireland's policy towards Vichy conformed to prevailing legal practice to a degree that is not normally appreciated.

15. Phyllis Gaffney, "Why was Ireland given Special Treatment”, art. cit., p. 153.

16. Dermot Keogh, Ireland and Europe, op. cit., p. 191.

17. Peter Davies, France and the Second World War: Occupation, Collaboration, and Resistance, London, Routledge, 2001, p. 56.

18. A substantial literature evaluates the internal politics of Vichy, but comparatively limited scholarship has been published on its foreign dimensions. For Vichy diplomacy see: Jean-Baptiste Duroselle, Politique étrangère de la France: L’Abîme, 1939-1944, Paris, Imprimerie nationale, 1982; Special issue: "Les politiques extérieures de la France pendant la deuxième Guerre Mondiale”, Relations Internationales, 107 (2001); Peter Jackson and Smith Kitson, "The Paradoxes of Vichy Foreign Policy, 1940-42", in J. R. Adelman (ed), Hitler and his Allies in World War II, Oxford, Oxford University Press, 2007, p. 79-115. For Vichy's domestic aspects see for exemplary purposes: Julian Jackson, France: The Dark Years, 1940-44, Oxford, Oxford University Press, 2001; Robert Paxton, Vichy France: Old Guard and New Order, London, Barrie \& Jenkins, 1972; François-Georges Dreyfus, Histoire de Vichy, Paris, Perrin, 1990; Robert Gildea, Marianne in Chains: In Search of the German Occupation, 1940-1945, London, Macmillan, 2002. 
The second portion of the article scrutinises Irish-French diplomacy after D-Day when the crisis relating to Murphy's reception by de Gaulle's forces gradually came to light. The primary attentions of this part are devoted to reconstructing the events that led to the Provisional Government's retreat from its demand to replace Murphy.

The methodology adopted by this article is a blend of a comparative framework and the empirical archival approach. It consists of a reading of international legal history and the recognition policies of other states, in combination with a close reading of primary sources (mainly diplomatic records) from the Archives of the Quai d'Orsay and the Irish National Archives during the crucial period of late September and early October 1944, when the fate of Seán Murphy hung in the balance. These archives house the historical records of the French Foreign Office and the Department of Foreign Affairs of Ireland ${ }^{19}$. In addition, the de Gaulle papers in the Archives nationales in Paris were consulted. The article will now examine Irish recognition policy and its attitude towards Vichy, in comparison to other states.

\section{圈 Recognition Policies}

Paula Wylie led the way with the systematic examination of Irish recognition policy from 1949 to $1963^{20}$, but nothing similar exists for the pre-1949 period of Irish diplomacy. In line with the Estrada Doctrine (1930) and the Montevideo Convention (1933), Eamon de Valera unyieldingly adhered to the view that "recognition of a state is irrevocable and anterior to a government" and "recognition [of a state] should be unconditional [i.e. not dependent on the government of that state ${ }^{21}$ ". Wylie identified de Valera's policy during the Spanish Civil War as the first example of such an Irish policy of recognition ${ }^{22}$.

However, there were several other examples of this practice before 1949, including the notorious incident involving de Valera's offer of condolences to the German Ambassador in the latter's private residence in May 1945 on the death of the German head of state, Adolf Hitler ${ }^{23}$. The legal argument was that de Valera was recognising the German state and not the Nazi Government or the person of Hitler. As early as September 1934, de Valera adopted similar legal thinking to argue for the Soviet Union's admission into the League of Nations, despite major domestic

19. The title of the department was Department of External Affairs until 1971.

20. P. L. Wylie, Ireland and the Cold War: Diplomacy and Recognition, 1949-63, Dublin, Irish Academic Press, 2006.

21. Ibid., p. 3, 5 .

22. Ibid., p. 2-3.

23. Dermot Keogh, "Eamon de Valera and Hitler: An Analysis of International Reaction to the Visit to the German Minister, May 1945", in Irish Studies in International Affairs, III, n 1 (1989), p. 69-92. 
Irish objections ${ }^{24}$. By so doing, Ireland recognised the Soviet Union as a de jure state and the Communist government as its de jure or legitimate government.

Identical Irish and international practice is observable in relation to Italy in October 1943. Then following the overthrow of Benito Mussolini and King Victor Emmanuel III's conferring of the post of Prime Minister on General Pietro Badoglio, Ireland continued to recognise the pre-existing Italian Minister to Ireland, Vincenzo Berardis: he had served the French state and not a particular government ${ }^{25}$. Likewise on his assumption of the Italian Premiership Badoglio automatically "notified the Diplomatic Corps [in Rome] that there was no constitutional change and that relations with Foreign States would continue as heretofore ${ }^{26 "}$.

There is greater continuity in Irish recognition policy under de Valera's direction before 1948 than is acknowledged in the pioneering work of Wylie or in empirical narratives of Irish foreign policy. In the case of Vichy France, Dublin observed the conventional interpretation of recognition that prevailed. It recognised the Republic of France and upheld diplomatic relations with the Vichy Government, but this did not imply approval of that state's system of government (authoritarian) or its policies (collaboration with the Nazis) even if such a powerful official as Joseph Walshe, the Secretary of External Affairs, was initially attracted by the religious, social and educational policies of Philippe Pétain ${ }^{27}$. Personal predilections were not considerations - international law demanded the maintenance of diplomatic relations. Conventional legal practice was upheld by the Irish state.

As can be detected, recognition is a complex concept in international law ${ }^{28}$. In recent times, the maintenance of full diplomatic relations has been portrayed popularly as a sign of approval of a government. But this is not a correct reading of traditional diplomatic practice and convention. It is a popular misconception that arose during the Cold War when on several occasions ideology overrode diplomatic convention and international law in the East-West conflict: the withdrawal of diplomats was employed as a device to signal disapproval of the policies

24. Michael Kennedy, Ireland and the League of Nations, 1919-1946: International Relations, Diplomacy and Politics, Dublin, Irish Academic Press, 1996, p. 199.

25. Memorandum by Rynne for Walshe, 15 October 1943, Doc. 335 in Documents on Irish Foreign Policy, vol viI, p. 347-349.

26. MacWhite to Walshe, 24 February 1944 (NAI, DFA SOF P 30).

27. Walshe's attraction to the political conservatism, authoritarianism and national regeneration policies of Pétain are fully covered in Dermot Keogh, "Ireland, de Gaulle and World War II", art. cit. Seán Murphy's efforts to correct Walshe's misconceptions are explored by Keogh.

28. See: G. R. Berridge, Diplomacy: Theory and Practice, Basingstoke, Macmillan, 2005, $3^{\text {rd }}$ edition, chapter 8; M. J. Peterson, Recognition of Governments: Legal Doctrine and State Practice, Basingstoke, Macmillan, 1997; T.D. Grant, The Recognition of States: Law and Practice in Debate and Evolution Westport, Praeger, CT, 1999; J.W. Young, Twentieth-Century Diplomacy: A Case Study of British Practice, Cambridge, Cambridge University Press, 2008, p. 199, n. 2. 
or actions of governments on the other side of the divide ${ }^{29}$. This was a diplomatic innovation and was legally contentious. The departure from convention was largely a product of the acute bipolar tensions.

The removal of diplomats as a sign of censure was not normally considered advisable before World War Two. It contravened the traditional interpretations. Full diplomatic relations was required once diplomats were exchanged between recognised de jure states; diplomatic relations were essential to maintain communications between states for the benefit of their citizens and the smooth functioning of international politics ${ }^{30}$. According to this perspective, governments and governance systems changed but the state persisted and it was the state, not the government, which was recognised. Individual governments were epiphenomena or transitory guardians of the state. The reciprocal exchange of diplomats and normal diplomatic relations were necessary to sustain unbroken exchanges and dialogue between two states when peace reigned between them. Diplomacy had a function to perform regardless of which government or what form of government ruled. Following the exchange of diplomats, bilateral diplomatic relations had to be maintained in the absence of hostilities, even if later governments were considered odious. Bearing this in mind, how did Irish diplomatic relations with Vichy compare to that of other states, both belligerent and neutral, after May 1940?

\section{Recognition of Vichy}

"In normal times" before the Fall of France in May 1940, approximately 61 diplomatic missions were present in France ${ }^{31}$. Two dynamic factors led to the decline in that tally after June 1940. First, the number was reduced as the Allied nations gradually withdrew their diplomats - it took time for them to determine if Vichy was a puppet of Germany. At the beginning, as Jean Lacouture perorates, Vichy's "international standing [...] was high enough for all the great powers with the exception of Britain [...] but including the USA, the USSR, the Third Reich, Italy, Japan, Spain and Canada (although a British dominion) to look upon it as the legitimate authority in France and to maintain their diplomatic relations with its government" after the summer of $1940^{32}$. Following the breaking off of relations, the Allies still regarded Vichy as the lawful custodian of the French state.

29. Peter Malanczuk, Akehurst's Modern Introduction to International Law, London, Routledge, $1997,7^{\text {th }}$ revised edition, p. 87. Previously the norm was to withdraw diplomatic relations on declaration of war.

30. The exchange and preservation of full diplomatic or even consular relations was not necessary for a state to recognise another as de jure; only Great Powers could afford the expense of global diplomatic and consular networks, small ones could not.

31. Murphy to Walshe, 2 January 1941 (NAI, DFA 219/1D).

32. Jean Lacouture, De Gaulle: The Rebel, 1890-1914, London, Norton, 1990, p. 283. 
Ireland, as a neutral, resisted Allied pressure to withdraw its diplomatic representatives from Vichy after 1942 on the grounds it would contravene neutrality ${ }^{33}$.

The second reason for the decline in diplomatic missions in France was that the conquered states under German or Soviet rule (Czechoslovakia, Poland, Latvia, Estonia, Lithuania, Norway, the Netherlands, Belgium, and Luxembourg) no longer existed as independent states. By January 1941, the foreign envoys (Nuncio, Ambassadors, Ministers, Chargé d'Affaires) of 36 countries remained accredited to Vichy ${ }^{34}$.

Britain was the first state to sever diplomatic relations with Vichy in July 1940. It did so in the aftermath of the Royal Navy's shelling the French Navy at Mers-el-Kébir on 3 July. This operation arose from British fears that the French Navy would fall into the possession of Germany following the signing of the Franco-German armistice. Britain did not declare war with France; however, it had no alternative but to withdraw its ambassador after its unprovoked attack. It still recognised Vichy as the de jure government of the Republic of France until the liberation in 1944. Britain sustained consular relations with the regime and Vichy's consuls remained in post in major British cities ${ }^{35}$. In July 1940 London recognised de Gaulle as the leader of all Free Frenchmen who rallied to the Allied cause outside of Vichy France. Thereafter, de facto recognition was expanded to include the French overseas territories that fell to de Gaulle's Free French ${ }^{36}$. It was not until Charles de Gaulle's CFLN possessed Metropolitan France in late 1944 that Britain recognised it as the legal government of the Republic of France ${ }^{37}$.

Initially, the United States' recognition policy towards Vichy and the Gaullist challenge paralleled Ireland's. Until the Japanese attacked Pearl Harbour, Washington maintained diplomatic relations with Vichy. On entering the war, it reassessed its stance towards Vichy in view of the growing evidence of the regime's collaboration with Nazi Germany. It finally had no alternative but to break relations with Vichy in November 1942, with the Anglo-American invasion of French North Africa (Operation Torch). This preparatory step for the invasion of southern Europe was a direct assault against the authority of Vichy. Nonetheless, it only withdrew de jure recognition from the Pétain government when it no longer controlled the territory of France ${ }^{38}$. Until that point, Washington resisted granting de Gaulle and the

33. See Lyn Gorman, "Australia and Vichy: The Impact of Divided France, 1940-1944", The Australian Journal of Politics and History, xxxxIII, $\mathrm{n}^{\circ} 2$ (1997).

34. Murphy to Walshe, 2 Jan. 1941 (NAI, DFA 219/1D).

35. Nicholas Atkin, Forgotten French: Exiles in the British Isles, 1940-1944, Manchester, Manchester U.P., 2003, p. 141-84.

36. Benjamin R. Payn, "French legislation in exile", Journal of Comparative Legislation and International Law, Third Series, xxviII, nº 3/4 (1946), p. 47-48.

37. Jean Lacouture, Rebel, op. cit., p. 353-54.

38. Stefan Talmon, Recognition of Governments in International Law: With Particular Reference to Governments in Exile, Oxford, Clarendon, 1998, p. 107, 297. 
CFLN legitimacy as claimants to the French state ${ }^{39}$. Washington finally recognised the GPRF as the de jure government of France in October $1944^{40}$. The relations between de Gaulle and America were notoriously embittered for the duration of the period from 1941 to 1944 . Milton Viorst has described them as 'hostile allies ${ }^{41}$ ', while Robert Dallek has memorably written: "The only thing worse than having allies is not having them, Churchill once said. When it came to each other Franklin Roosevelt and Charles de Gaulle were not so sure ${ }^{42}$."

Until 1944, Dublin maintained the externalities of neutrality in common with fellow neutrals and nonaligned states. It was important to fall into step with the precedents set by the traditional neutral states, Switzerland and Sweden, as well as the Vatican. The latter retained a potent influence on the Irish mind for religious reasons, but this was especially the case with the Irish foreign policy mandarin, Joseph Walshe. In common with practically all states possessing a diplomatic relationship with the Republic of France before May 1940, Dublin recognised Vichy as the lawful government of France thereafter. As a neutral it preserved full diplomatic relations with it until 1944; a premature withdrawal of Irish diplomats from Vichy could be construed as a sign of censure. In August 1944 German forces compelled Pétain to leave France, the Allied invasion of France was succeeding and Adolf Hitler did not want Pétain falling into Allied hands ${ }^{43}$. Thus far, Ireland had consistently conformed to the standard practices of neutral states by rejecting Allied pressure to withdraw its diplomatic mission from Vichy. To do

39. Stefan Talmon, "Who is a Legitimate Government in Exile? Towards Normative Criteria for Governmental Legitimacy in International Law", in Guy S. Goodwin-Gill and Stefan Talmon (eds), The Reality of International Law: Essays in Honour of Ian Brownlie, Oxford, Clarendon, 1999, p. 510.

40. See the useful overview: Denis Peschanski, "Legitimacy/Legitimation/Delegitimation: France in the Dark Years, a Textbook Case", Contemporary European History, XIII, n 4 (2004), p. 409-23.

41. Milton Viorst, Hostile Allies, New York, Macmillan, 1965.

42. Robert Dallek, Franklin D. Roosevelt and American Foreign Policy, 1932-1945, New York, Oxford UP, 1995, p. 406. Vast historical evidence reiterates this incontrovertible conclusion and there remains much heated debate in French and American literature: was the United States correct in seeking to displace de Gaulle as leader of the Free French or not? The long-running dispute is central in all scholarly work on de Gaulle's relationship with the US during World War Two. Two overviews of the situation are: Robert Dallek, "Roosevelt and de Gaulle", in Robert O. Paxton and Nicholas Wahl (eds.), De Gaulle and the United States: A Centennial Reappraisal, Oxford, Berg, 1994, pp 49-60; Kim Muholland, "The United States and the Free French", in Paxton et al., De Gaulle and the United States, p. 61-94. But see also: Julian G. Hurstfield, America and the French Nation, 1939-1945, Chapel Hill, NC: University of North Carolina Press, 1986. Evidence of FDR's hostility towards de Gaulle is widespread throughout Winston Churchill and Franklin Delano Roosevelt's correspondence. See Francis L. Loewenheim, Harold D. Langley and Manfred Jonas (eds.), Roosevelt and Churchill: Their Secret Wartime Correspondence, London, Barrie \& Jenkins, 1975, p. 63, 251 n. 3, 335 n. 2, 338, 344, 345, 484 n. 2, 541. Churchill and the British authorities used their diplomatic and rhetorical powers on numerous occasions to avoid Washington DC's abandonment of de Gaulle. For example, see: Thomas R. Christofferson and Michael S. Christofferson, France during World War II: From Defeat to Liberation, New York, Fordham University Press, 2006, p. 135-136; François Kersaudy, Churchill and de Gaulle, London, Fontana, 1990.

43. Stefan Talmon, Recognition of Governments, op. cit., p. 107. 
otherwise would signify political disapproval; this would contradict both neutrality and the traditional interpretation of international law.

Regardless, the Irish government prepared for the diplomatic repercussions of the fall of Vichy and the Gaullist ascendancy. At this point close attention must be devoted to the Irish thinking underlying the decision to recognise de Gaulle's diplomats as the agents of the effective government of France in August 1944. The transition commenced in mid-1943.

\section{Recognition of the CFLN/GPRF}

On 3 June 1943, following the establishment of Allied control of French North Africa, Generals Giraud and de Gaulle founded the CFLN (encompassing the Free French) with Allied backing in Algiers. Within months de Gaulle outmanoeuvred Giraud and took sole leadership of the CFLN. The CFLN had jurisdiction over all the overseas territories liberated from Vichy and all French armed forces fighting Vichy. Recognising the oscillation in power politics, Dublin extended de facto recognition to the CFLN in November 1943 and the committee's representative in Dublin. This acknowledged its factual existence (territorial jurisdiction and capacity to enter relations in late 1943) in non-Metropolitan France and it led to the extension of consular relations to the CFLN's representatives ${ }^{44}$.

The Department of External Affairs intended to phase out the Vichy mission as the de jure mission of the Republic of France to reflect military and political realities when appropriate (it was widely known that preparations for an Allied invasion of Western Europe were proceeding). The Vichy mission in Dublin was headed by M. Cauvet-Duhamel, who was known as a covert adherent to the CFLN (a form of double agent) by the Irish authorities. From late 1943 Ireland planned to replace the Vichy mission, with the full agreement of Cauvet-Duhamel, with a CFLN one as the de jure mission when Vichy was no longer an effective entity in France. Joseph Walshe's concern was that the transition from Vichy to CFLN should not be publicised. Walshe and Iveagh House wished to avoid a public controversy and that diplomatic representation could smoothly transition ${ }^{45}$.

The CFLN, led by de Gaulle, claimed the title of GPRF or Provisional Government on 2 June $1944^{46}$. De Gaulle did not inform his allies, the US and UK, in advance. The Allies landed on the beaches of Normandy on 6 June 1944. Six days later the GPRF sent M. Lalouette to Dublin without providing advance notice to the Irish authorities. The GPRF instructed Lalouette to take up the post of secretary to the GPRF representative in Dublin, M. de Laforcade. On

\footnotetext{
44. Robert Patterson, "Ireland, Vichy and Post-Liberation France", art. cit., p. 109.

45. Walshe memorandum, 22 June 1944 (NAI, DFA, SOF, A 2).

46. Stefan Talmon, Recognition of Governments, op. cit., p. 79.
} 
his arrival, Walshe personally informed him and de Laforcade that Ireland would assist French reunification as it had no quarrel with any French faction. He also granted permission to Cauvet-Duhamel to go to the headquarters of the GPRF in Algiers to end his "equivocal situation" in late June 1944, whereby he acted as Chargé d'Affaires of Vichy in Dublin but secretly obeyed the CFLN ${ }^{47}$.

However, until Pétain had actually fallen, External Affairs was only prepared to extend de facto recognition to the CFLN and de Gaulle. On 21 August, the department's attitude was "to deal with the de facto authorities as they arise [in France] and to postpone defining [the Irish] position until authority becomes properly established [in France] ${ }^{48}$ ". Following Pétain's declaration (23/34 August 1944) that he no longer effectively controlled the French state, the way was clear for Ireland to transfer diplomatic relations ${ }^{49}$. De Gaulle and the CFLN/GPRF marched victoriously down the Champs-Élysées on 26 August. A prompt decision was arrived at in Iveagh House that the GPRF controlled France de jure. On 29 August de Laforcade was informed Ireland accepted him "in the fullest sense as Minister of France". Walshe outlined the position:

Our country did not want to play politics with France. Our sole interest was to remain on friendly terms with his country, and we did not feel called upon to make a special declaration of recognition, our assumption being that it was exclusively the business of the French people. We preferred to regard ourselves as having been in continuing relations with France [the state], and we hoped for that and other reasons that it would not be necessary for Mr. Murphy to present new credentials. His credentials had been presented in 1938 to the Head of the French Republic, and the new Government, in so far as we were concerned, did not constitute any change in France's governmental regime ${ }^{50}$. [Author's italics]

Remarkably, this Irish acknowledgement of the GPRF as the Government of the Republic of France predated comparable action on the part of the US and Britain by a comparable margin; as de Gaulle's allies they should have acted expeditiously to formalise recognition of the new government. The UK and the US only granted GPRF representatives "the use" of the former French Embassies in their countries on 14 September $^{51}$. It was not until 22 October 1944 that the Supreme Allied Commander formally transferred administrative control of France

\footnotetext{
47. Walshe memorandum, 22 June 1944 (NAI, DFA, SOF, A 2).

48. Estero to Hibernia Vatican City, Personal Code Telegram, 21 August 1944 (NAI, DFA, SOF, P 97).

49. Stefan Talmon, Recognition of Governments, op. cit., p. 297.

50. Walshe memo, "Recognition of Monsieur de Laforcade as Minister of the new French Government in Dublin", 29 August 1944 (NAI, DFA, SOF, P 97).

51. Stefan Talmon, Recognition of Governments, op. cit., p. 193, $\mathrm{n}^{\circ} 422$.
} 
and Paris to the GPRF 52 . The British and American governments officially recognised the CFLN as the Provisional Government of France on 23 October 1944, two months after the Irish ${ }^{53}$. This Allied delay hinted at misgivings, particularly in the US, about sanctifying the accession of their vexing ally, Charles de Gaulle. If the Irish estimated their early recognition of the GPRF would purchase enhanced Irish-French relations, they were swiftly disabused.

\section{圈 "No such persons are accredited to the French Republic"}

The GPRF refused to recognise diplomats who had represented neutral governments at Vichy as heads of mission. Walshe received the first hints of its intentions in June 1944, but he discounted the possibility - it questioned the basis of a state to maintain neutrality under international law ${ }^{54}$. In late August, de Laforcade reminded Walshe of the GPRF's demand for a new Irish Minister to replace Murphy. Murphy was no longer acceptable as a diplomat representing Ireland to the Republic of France owing to "his long relations with the Vichy Government ${ }^{55}$ ".

The chaotic liberation and immediate post-liberation phases confounded Walshe's efforts to regularise the situation. Communications were utterly disrupted between Walshe and Murphy from at least early August until the end of September 1944. Walshe conducted talks with Laforcade regarding the recognition question and demanded Murphy's retention "almost exclusively" through the French Legation in Dublin during this blackout ${ }^{56}$. The GPRF's treatment of Murphy perplexed Walshe in light of his interpretation of international law as it related to neutrality, diplomatic accreditation and relations between states. Walshe assumed his conversations with Laforcade would have the desired effect, and Laforcade's reports to French Foreign Office in September revealed his sympathy for Walshe's argumentation which he fatefully reproduced for his superiors. The French Minister's report of 19 September informed the Quai of Walshe's threat to remove recognition from the GPRF delegation as the de jure representatives of the Republic of France, if the Quai failed to grant reciprocity to Seán Murphy. Laforcade's report was conspicuously sympathetic to the Irish position for several

52. Ibid., p. 79-80.

53. Ibid., p. 212; Jean-Claude Allain, Pierre Guillen, Georges-Henri Soutou, Laurent Theis \& Maurice Vaïsse, Histoire de la Diplomatie Française, Paris, Perrin, 2007, vol. II, p. 359.

54. Walshe to Murphy, 30 September 1944 (NAI, DFA, SOF, P 97).

55. Walshe Memo, "Recognition of Monsieur de Laforcade as Minister of the New French Government in Dublin", 29 August 1944, ibid.

56. For Walshe's summation of the communication problems see: Walshe memorandum, "Recognition of New French Government", n.d. (c. late October or early November 1944), ibid. 
reasons (the Irish Red Cross hospital, the letters of credence complications, French international influence, the pro-French sentiments of Ireland) ${ }^{57}$.

Highlighting Iveagh House's grave concerns about Murphy's safety and whereabouts in the chaotic warzone, Iveagh House vainly despatched repeated messages to Murphy as Vichy tumbled and the GPRF claimed control. For instance, in mid-August, Dublin telegrammed Murphy: "take no risks", keep in "close touch with neutral colleagues especially the Papal Nuncio" and be guided by their general attitudes as the situation developed ${ }^{58}$. It is unclear if Murphy received this or other instructions emitting from Iveagh House in August, but he made his way from Vichy to Paris with a convoy of the fellow neutral diplomats to establish relations with the new Provisional Government ${ }^{59}$. He arrived in Paris on Monday, 25 September $1944^{60}$.

In the absence of contact Walshe was unaware of Murphy's arrival in Paris. A few days later in late September or early October he read the disturbing report of Reuter's special correspondent in Paris with the dateline of 27 September. Harold King recounted that ten diplomats formerly accredited to Vichy had recently arrived in Paris headed by the Papal Nuncio. An unbending Quai d'Orsay, now under the control of the GPRF, upheld the policy conveyed to Walshe by Laforcade: it regarded Murphy and his neutral colleagues as "private persons". An official stated: "We do not know any of these people [...] No such persons are accredited to the French Republic ${ }^{61}$." Walshe was astonished.

Laforcade's efforts to represent Irish interests to his superiors in the Quai had conspicuously failed. In addition, Laforcade experienced pronounced difficulty in communicating with Paris during the period of August and September, which aggravated the situation. Iveagh House's imperative was to search for alternative lines of negotiation. Murphy was unreachable, but he was in Paris according to Reuters. Walshe urgently needed to instruct him to engage directly in negotiations with the Quai. It was imperative to brief Murphy to empower him to plead his case accurately with the Quai. In these exceptional circumstances, Walshe directed the Irish High Commissioner to London, John Dulanty, to approach René Massigli, the newly appointed French ambassador in London ${ }^{62}$. This turned out to be a masterstroke: Massigli became the key to overcoming the Quai's resistance.

57. Laforcade to Affaires Étrangères, 19 September 1944 (AEAD, Europe, Irlande 1944-1949, vol. 219, n 3 ).

58. Estero (Dublin) to Hibernia (Vichy), Telegram, 16 August 1944, ibid.

59. Murphy to Walshe, 28 September 1944, ibid. This minute was not received in External Affairs until 18 October 1944.

60. Murphy to Walshe, 28 September 1944 (NAI, DFA SOF P 97). Received on Tuesday 18 October 1944.

61. Report of Harold King, Reuter's Special Correspondent, Paris, 27 September 1944, ibid.

62. Walshe to Murphy, 30 September 1944 (NAI, DFA, SOF, P 97). 


\section{The Massigli Connection}

As it transpired Massigli was a distinguished Gaullist and his advice commanded attention in the Quai. A senior French professional diplomat with international connections before 1940, he was a "faithful" devotee of de Gaulle ${ }^{63}$. The General held him in high esteem ${ }^{64}$ and invited him to London in 1942 to take up the post of Commissioner of Foreign Affairs of the CFLN. He occupied this until August 1944 when, following the GPRF's assertion of authority, de Gaulle appointed him as the Ambassador of France to Britain. St James Court was a key posting ${ }^{65}$.

In carrying out his instructions and speaking directly to Massigli, the Irish High Commissioner was assured of a high level hearing in Paris. On 29 September Dulanty met with Massigli and familiarised the Frenchman with the controversy and the communications breakdown for "the past ten weeks". Massigli volunteered to use his diplomatic bag to forward Walshe's instructions to Murphy ${ }^{66}$. Massigli, a veteran diplomat, recognised the grave situation: Walshe was unshakeable in his determination to retain Murphy as minister perceiving that the Quai had affronted Ireland's neutrality.

To prevent escalation, Massigli extracted a promise that Iveagh House would not revoke Laforcade's recognition until he received clarification from the Quai. Then he telegrammed the Quai :

Si l'attitude de M. Murphy à Vichy n'a pas donné lieu à des remarques particulièrement défavorables, il semble que le Gouvernement Provisoire peut - sill le juge opportun - retenir cet argument pour admettre M. Murphy à continuer à exercer ses fonctions au moins à titre temporaire. Cette attitude conciliante ne nous empêcherait pas de marquer au Gouvernement irlandais notre désir de voir se prolonger le moins possible la situation ainsi créée ${ }^{67}$.

The Quai d'Orsay file contains a translation of Walshe's letter for Murphy ${ }^{68}$. Whether the Irish made this available or the Quai opened it before transmit-

63. Jean Lacouture, Rebel, op. cit., p. 445.

64. In his memoirs de Gaulle refers to him as a man "of quality" and one of the "notables". Charles de Gaulle, The Complete War Memoirs of Charles de Gaulle, Forge Village, Mass., Clarion/Simon \& Schuster, 1972, p. 318, 403.

65. Claire Andrieu, Philippe Braud et Guillaume Piketty, Dictionnaire de Gaulle, Paris, Robert Laffont, 1996, p. 734. This was a demotion according to some authors who claim that Massigli was too anglophile for de Gaulle's tastes. See Martin Thomas, "Free France, the British Government and the Future of French Indochina 1940-45", in Paul H. Kratoska (ed.). Independence through Revolutionary War, London, Routledge, p. 223-251. 66. Walshe to Murphy, 30 September 1944 (NAI, DFA, SOF, P 97).

67. Massigli to Paris, Diplo 4880, 30 September 1944 (AEAD, Europe, Irlande 1944-1949, vol. 214, $\mathrm{n}^{\circ}$ 2).

68. Traduction, Lettre de Joseph Walshe à Sean Murphy, 30 Sept. 1944 (AEAD, Europe, Irlande 1944-1949, vol. 214, $\left.\mathrm{n}^{\circ} 2\right)$. 
ting it to Murphy is unclear. Regardless, the Quai was in no doubt about Walshe's intentions to retaliate in kind. In his instructions to Murphy, Walshe informed his subordinate that Ireland was "still somewhat mystified by some aspects of our relations with the French Government". He directed Murphy to approach the Quai again to explain the position of Ireland, which he outlined in detail in his three page letter. Walshe informed Murphy that the GPRF's suggestion that he should be replaced "could only be regarded as a somewhat unfriendly gesture directed against the Government rather than the representative of the neutral country concerned". In the "disagreeable eventuality" that the Foreign Office persisted in its refusal to recognise Murphy as head of the Irish mission to France, Walshe commanded Murphy to apprise the Quai: "We shall feel obliged to our very great regret to withdraw our recognition from $M$. de Laforcade, a recognition which was granted on the hypothesis that there would be no question about recognition of your position on the other side ${ }^{69}$."

Georges Bidault read and responded to Massigli's telegram on 4 October:

En réponse à votre télégramme no. 4880, je suis heureux de pouvoir vous faire savoir que le Gouvernement provisoire de la République donne volontiers son agrément en maintien de M. Murphy en qualité de Ministre de l'Irlande à Paris. Il y aurait lieu de prévoir pour lui la présentation de nouvelles lettres de créance $^{70}$.

Matters were approaching a resolution. Bidault, lacking full knowledge of the Irish case, was willing to keep Murphy but new letters of accreditation were requested. As detected, the latter condition was unpalatable to Ireland, but Bidault conceded that Murphy was acceptable in principle, which was substantive progress. However, on 5 October Walshe received a telegram from Murphy providing a disheartening account of his failed effort to convince the Quai. As instructed, Murphy had met the Secretary General of the Foreign Office, Raymond Brugère. He reported: "I was very coldly received and rudely received by the Secretary General." Brugère had bristled at the repetition of the argument that for Ireland "the Government de facto was the Government de jure, and the moment the Pétain Government had disappeared", Ireland automatically entered into relations with the new government ${ }^{71}$. Brugère "became irritable at the mention of the word 'de facto'". Murphy was rejected again and he was provided with no resources to communicate to Iveagh House ${ }^{72}$. Murphy's Legation colleague, Mr MacDonald, had to physically travel to the Irish Legation in Switzerland to

69. Walshe to Murphy, 30 September 1944 (NAI, DFA, SOF, P 97).

70. Bidault to London, $\mathrm{n}^{\circ}$ 122, 4 October 1944, (AEAD, Europe, Irlande 1944-1949, vol. 214, $\mathrm{n}^{\circ} 2$ ).

71. Walshe to Murphy, 30 September 1944 (NAI, DFA, SOF, P 97).

72. Ibid. 
despatch the telegram outlining the Quai's second rebuff ${ }^{73}$. This underscored the lack of consideration shown to Murphy. The Irish representative reported gloomily on conditions as he saw them: "The general impression of the Foreign Office was excitable $[s i c]$ truculent. The Administration generally is chaotic ${ }^{74}$."

Why had the Secretary-General rejected Murphy so severely in view of the French Foreign Minister's alteration of attitude? Poor timing was at play. Bidault responded to Massigli's telegram on 4 October. No date is provided for the second rebuke the Secretary-General delivered to Murphy, but it probably predated 4 October. It was unlikely that MacDonald travelled from Paris to Berne within 24 hours to have Murphy's telegram transmitted to Dublin, particularly in the conditions prevailing in France in early October 1944. There was no mention in Murphy's telegram that new letters of credence were required to remain in post, which indicated Brugère had not been updated on Bidault's recent decision.

Since Massigli had expedited communication with Murphy on 30 September and evinced sensitivity, Walshe pursued that link. This had the advantage of snubbing Laforcade and signalled the intention to withdraw recognition. Walshe phoned the Irish High Commissioner in London, John Dulanty, on the morning of 6 October to request the lodging of a protest with the French Embassy against the Quai's unsatisfactory reception of Murphy, its failure to accept Murphy as minister and its implied derision of Irish neutrality. The High Commission immediately sent its Counsellor, John Belton, to the embassy to deliver the protest and to request that it forward a letter to Murphy. Massigli agreed to transmit Walshe's formal protest to the Quai, which included the following:

Rudeness to our representative was rudeness to Government [...] We expected [an] immediate apology and complete acceptance of our representative [...] Failing that we should be obliged to withdraw our recognition from the French Legation here. [...] [W]e had no alternative as [our] Government could not without sacrificing its sovereign right, allow its representative to be so treated or its right to neutrality so impugned ${ }^{75}$.

Walshe's instructions to Murphy were: as a small country Ireland did not "play politics" with recognition matters and a solution had to be negotiated with France "to put things right". He admitted that the Quai's treatment of Murphy was probably "due to frayed temper and inevitable annoyance with Vichy". But Murphy was told to make contact with Paris again, "Another talk with Secretary General might put everything right". Walshe had not retreated from his elementary posi-

73. Hibernia to Estero Dublin, Telegram from Berne, 4 October 1944 (NAI, DFA, SOF, P 97).

74. Ibid.

75. Estero to Hibernia (Berne), For Murphy, Telegram No. 103 Dearg, 9 October 1944 (NAI, DFA, SOF, P 97). 
tion: it was paramount that Murphy was recognised as the Irish minister to enable "full relations" between the two countries ${ }^{76}$.

At this point Massigli interceded again. He transmitted an extensive telegram to the Quai on 6 October. Believing that his previous suggestions had fallen on deaf ears, he reiterated that Murphy's mission should be extended on the basis that his accreditation to France occurred in 1938 prior to the Vichy interlude. His extension could be subject to an assessment of his activities under the Vichy regime to determine whether he had revealed pro-Vichy tendencies between 1940 and 1944. Massigli deduced that France had "little reason to be angry at Ireland's neutrality", unlike London and Washington ("nous n'avons guère de raison de tenir rigueur à l'Irlande de sa neutralité plus que ne le font Londres et Washington") ${ }^{77}$. France's material interests had not been deleteriously affected by Ireland. Massigli's judgement could not be dismissed easily.

Particularly instructive are the lines of the telegram which were marked by a Quai official in the margin: "M. Murphy se plaindrait d'avoir été très mal reçu. Il se plaindrait, notamment, d'allusions qui auraient été faites en sa présence à la neutralité irlandaise. Enfin, on lui aurait indiqué très clairement que le Gouvernement Provisoire ne pouvait admettre le principe de son maintien à Paris en qualité de Ministre d'Irlande." "Position révisée" is written in the margin opposite this final sentence. A further sentence of Massigli's telegram had a vertical line drawn in the margin next to it: "Le Gouvernement Irlandais, ayant ipso facto reconnu le Gouvernement Provisoire, compte que son représentant en France bénéficiera du même traitement que M. de Laforcade à Dublin." The vertical pencil line is accompanied by a handwritten "Oui", signifying agreement on the part of the official reading the document $^{78}$. The marginalia highlight the points considered salient by the Quai official. The assertion that Irish neutrality was affronted by the Quai in the presence of Murphy was identified as fateful; Walshe was not prepared to compromise. France's unyielding application of the policy of not accepting foreign heads of missions who had served in Vichy imperilled cordial Irish-French relations.

The Quai official who annotated Massigli's telegram wrote a brief note on it for Roger Gaucheron. This has proved challenging to decipher, but it appears to read: "La situation est disposée - les éléments d'une mise un point ${ }^{79}$." In subsequent correspondence on 17 November 1944 Murphy informed Iveagh House that Roger Gaucheron was "our friend" and "the person in the political section who deals with Ireland amongst other counties ${ }^{80}$ ". Serendipity played a part in the offi-

76. London to Quai, Tel. No. 4,947 (AEAD, Europe, Irlande 1944-1949, vol. 214, $\mathrm{n}^{\circ}$ 2).

77. Ibid.

78. Ibid.

79. Ibid.

80. Murphy to Walshe, 17 November 1944 (NAI, DFA, SOF, P 97). 
cial forwarding Massigli's telegram for Gaucheron's attention; Gaucheron was the appointed Secretary of the French Legation in Dublin in 1930 when the legation first opened in Dublin ${ }^{81}$. As a result of this posting in the early 1930s, Gaucheron comprehended the Irish national position to some degree. It is probable, therefore, that Gaucheron was responsible for transmitting the Massigli telegram to President de Gaulle. De Gaulle was correctly concerned and he wrote a note to a member of his staff, Etienne Burin des Roziers, responsible for relations with the Quai d'Orsay:

\section{Pourquoi a-t-on mal reçu M. Murphy, ministre d'Irlande?}

2. Je voudrais connaître le point de vue de M. Bidault sur la question de nos relations avec l'Irlande à laquelle je pense que nous devons attacher $d u$ soin et de l'importance ${ }^{82}$.

Keogh, Patterson and Gillissen all argue that this intervention by de Gaulle reversed the Quai's attitude. De Gaulle's terse question and comment suggested care should be taken in France's relations with Ireland. Massigli's emphasis on relaying the bad reception Murphy had received and the objectionable implications transmitted regarding Irish neutrality had an effect. Perhaps de Gaulle, following his long struggle for the "soul of France" in Winston Churchill's words, appreciated that Irish neutrality and its diplomatic requirements were vital in Irish endeavours to fortify political and foreign policy independence, in the same way that the Free French had depended on appeals to legitimacy, legalism and the performative ${ }^{83}$ ? Numbered among de Gaulle's ancestors were the McCartans of County Down who rebelled against English Law. He was knowledgeable of Irish history and held Daniel O'Connell in high estimation ${ }^{84}$.

Ironically, de Gaulle's arresting interposition was in all likelihood unnecessary. But it underwrote Bidault's softened line of 4 October and subsequently eased flexibility on the letters of credence. Bidault, Massigli, Gaucheron and de Gaulle were all of a common view now to accommodate Murphy's retention. Walshe's unbending perseverance since August had succeeded. Eamon de Valera as the Minister for External Affairs was responsible for sanctioning Walshe's rigid

81. Gaucheron is identified as the inaugural Secretary of the Legation at: The Residence of France and its History, [http://www.ambafrance-ie.org/La-Residence-de-France-et-son] (accessed 12 February 2016).

82. De Gaulle to Burin des Roziers, note, "after 6 October" (Archives Nationales, Paris, Archives de la Président de la République : Charles de Gaulle, 3 AG 4/14). I am very grateful to Professor Christophe Gillissen for drawing my attention to this.

83. Regarding the contingency and utility of legitimacy as practiced by de Gaulle see: Denis Peschanki, "Legitimacy/Legitimation/Delegitimation: France in the Dark Years, a Textbook Case", Contemporary European History, 13, 4 (November 2004), p. 409-423.

84. Pierre Joannon, "Charles de Gaulle and Ireland: A return to the sources", in Joannon, De Gaulle and Ireland, p. 5-7; Jean Lacouture, De Gaulle: The Ruler, 1945-1970, London, Harvill, 1992, p. 579-80. 
defence of neutrality in the closing months of World War Two, and the resolute Irish demand for keeping Murphy in France after the fall of Vichy conforms to this pattern.

\section{An Audience with de Gaulle}

The matter was not completely resolved as Phyllis Gaffney has revealed after the Quai relented on its demands for new letter of credence to be granted. Murphy still had to visit the new Head of Government in line with diplomatic custom. However, if Murphy was granted an official audience this would publicise the "Irish exception". Iveagh House and the Quai negotiated a compromise. Murphy had been due to return home to Ireland for debriefing and long overdue leave. He had been trapped with his family in France by the war since 1940. Murphy's taking of extended leave provided the Quai with a solution. It would allow the thorny issue of neutrals' representation to recede from the public eye, and purchase time to engineer a low-key way to satisfy the need for an audience with de Gaulle ${ }^{85}$.

On his return to Paris, Murphy visited de Gaulle on Saturday, March 24, 1945 , "in what was described as 'a private audience" as opposed to a formal state audience. This proved to be a "cordial" affair. Murphy transmitted de Valera's best wishes for de Gaulle's personal wellbeing and his desire "to see France very soon retake her place amongst the great nations of the world". A "very touched" de Gaulle responded in a telling fashion: "Ireland and France had always been friendly. There was no reason to quarrel [...] He hoped, that after the war, the economic and cultural relations between the two countries would become closer. We shall all need our friends after the war. He expressed his great admiration for the Taoiseach and the manner in which he had kept his country neutral [author's italics] ${ }^{86 . " ~ D e ~ G a u l l e ' s ~}$ words suggest sentimental factors played a role in solving the Franco-Irish diplomatic crisis. De Gaulle understood that in de Valera's situation he would have adopted a similar neutrality policy during World War Two. De Gaulle, as a French nationalist and an exponent of the primacy of the nation-state in international politics, was sensitive to respecting other states' national interests and Ireland was a friend of France. He respected the Irish government's perspective.

\section{圈 Conclusion}

In sum, the resolution of the Seán Murphy enigma does not reside in an Alphand-Boland "back channel" or the possible "complementary" factors identi- 
fied by Gaffney. Complementary factors may have assisted, but there is no direct evidence that they did and they were not the primary actors or causes initiating the special consideration in any case. The primary considerations were mutual respect of national interests and their accommodation. Keogh was correct: a French diplomat who had served in the French Legation in Dublin in the early 1930s played a central part in resolving the case. But it was Roger Gaucheron rather than Hervé Alphand, and it was not an Irish "back channel". Secondly, Keogh and other authors are correct in underlining de Gaulle's role in the resolution of the accreditation crisis, but only to a degree. Georges Bidault's line had softened significantly. De Gaulle's intrusion in Quai matters made subsequent relaxation on the letters of credence easier. Principally, it was the experienced French diplomat, René Massigli, who played the role as the initiator in the granting of the Irish exception. Massigli and serendipity had avoided a major crisis in Franco-Irish relations. 